\title{
Status of the Verna's Flower Moth (Schinia verna) in Alberta
}

\section{Fish \& Wildlife Division}

\section{SPECIESAT RISK}

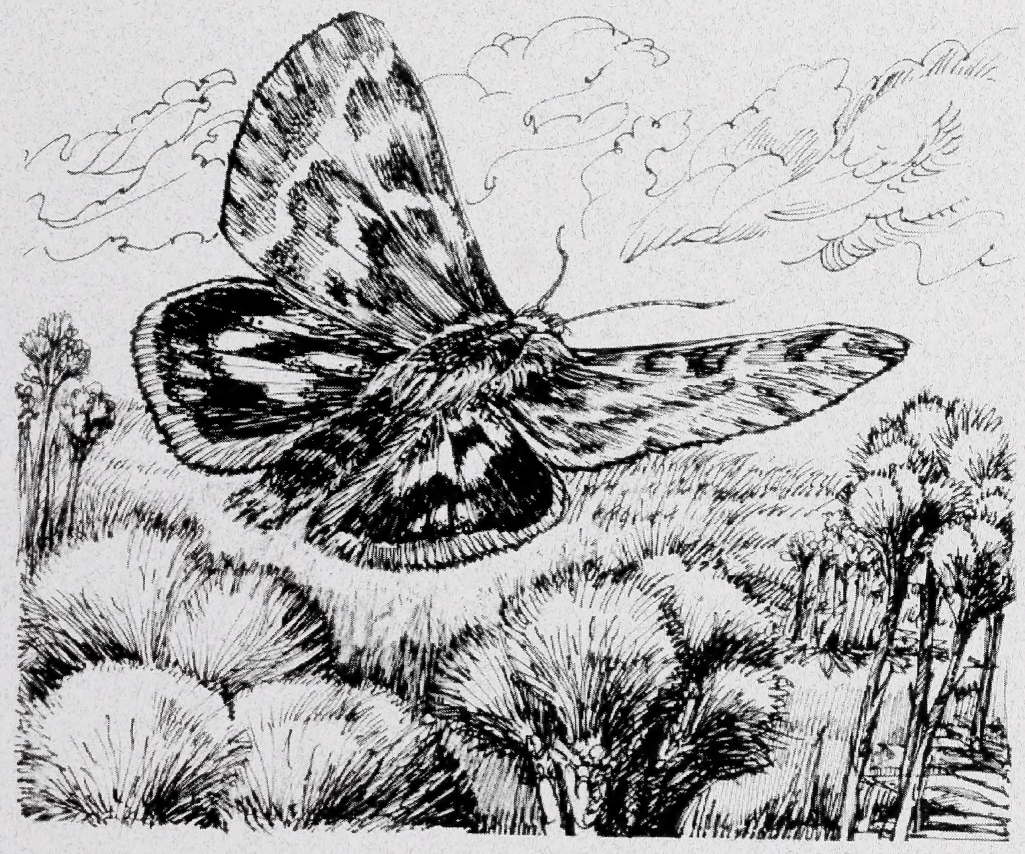

Alberta Wildlife Status Report No. 65

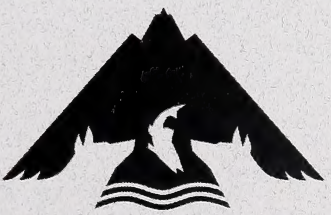





\title{
Status of the Verna's Flower Moth (Schinia verna) in Alberta
}

\author{
Prepared for: \\ Alberta Sustainable Resource Development (SRD) \\ Alberta Conservation Association (ACA)
}

Prepared by:

Gary Anweiler

This report has been reviewed, revised, and edited prior to publication.

It is an SRD/ACA working document that will be revised and updated periodically.

Alberta Wildlife Status Report No. 65

April 2008

Published By:
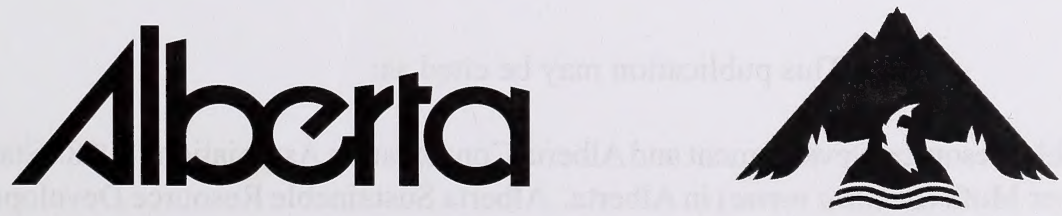

Alberta Conservation Association 
Publication No. T/178

ISBN: 978-0-7785-7017-2 (Printed Edition)

ISBN: 978-0-7785-7018-9 (On-line Edition)

ISSN: 1206-4912 (Printed Edition)

ISSN: 1499-4682 (On-line Edition)

Series Editors: Sue Peters, Robin Gutsell and Lisa Matthias

Illustrations: Brian Huffman

Maps: Nicole Hopkins

For copies of this report, visit our web site at:

http://srd.alberta.ca/fishwildlife/speciesatrisk/ and click on "Detailed Status"

OR

Contact:

Information Centre - Publications

Alberta Sustainable Resource Development

Main Floor, Great West Life Building

9920 - 108 Street

Edmonton, Alberta, Canada T5K 2M4

Telephone: (780) 944-0313 or 1-877-944-0313

This publication may be cited as:

Alberta Sustainable Resource Development and Alberta Conservation Association. 2008. Status of the Verna's Flower Moth (Schinia verna) in Alberta. Alberta Sustainable Resource Development, Wildlife Status Report No. 65, Edmonton, AB. 17 pp. 


\section{PREFACE}

Every five years, the Fish and Wildlife Division of Alberta Sustainable Resource Development reviews the general status of wildlife species in Alberta. These overviews, which have been conducted in 1991 (The Status of Alberta Wildlife), 1996 (The Status of Alberta Wildlife), 2000 (The General Status of Alberta Wild Species 2000), and 2005 (The General Status of Alberta Wild Species 2005) assign individual species "ranks" that reflect the perceived level of risk to populations that occur in the province. Such designations are determined from extensive consultations with professional and amateur biologists, and from a variety of readily available sources of population data. A key objective of these reviews is to identify species that may be considered for more detailed status determinations.

The Alberta Wildlife Status Report Series is an extension of the general status exercise, and provides comprehensive current summaries of the biological status of selected wildlife species in Alberta. Priority is given to species that are At Risk or May Be At Risk in the province, that are of uncertain status (Undetermined), or that are considered to be at risk at a national level by the Committee on the Status of Endangered Wildlife in Canada (COSEWIC).

Reports in this series are published and distributed by the Alberta Conservation Association and the Fish and Wildlife Division of Alberta Sustainable Resource Development. They are intended to provide detailed and up-to-date information that will be useful to resource professionals for managing populations of species and their habitats in the province. The reports are also designed to provide current information that will assist Alberta's Endangered Species Conservation Committee in identifying species that may be formally designated as Endangered or Threatened under Alberta's Wildlife Act. To achieve these goals, the reports have been authored and/or reviewed by individuals with unique local expertise in the biology and management of each species. 


\section{EXECUTIVE SUMMARY}

Verna's flower moth (Schinia verna) is a small, day-flying moth with a global distribution limited to the Grassland and Parkland natural regions of the southern Prairie Provinces. It is known from only five sites, three of which are in Alberta. Only single individuals have been found at four of the five sites, including all three Alberta sites. Two of the Alberta sites were located only recently (2000 and 2007); the third is an historical record from 1929. Both recent sites are located on privately owned land. In 2005, Verna's flower moth was assigned a national status of Threatened by COSEWIC (Committee on the Status of Endangered Wildlife in Canada).

Verna's flower moth is found in cattle-grazed, native grassland pastures. It is dependent upon one or more species of a single genus of native plants, pussytoes (Antennaria sp., Asteraceae), for reproduction. Larval feeding is confined to the flowering parts of the plant (flowers, seeds and seed capsules) and the life cycle of this moth is intimately linked with the blossoming cycle of the host plant.

Verna's flower moth is extremely difficult to identify and observe in the wild; consequently, little is known about population sizes, trends and any of the factors influencing them. There is an abundance of apparently suitable habitat available throughout the range of the moth, but very few of the moths have ever been encountered. Although Verna's flower moth's apparent rarity may in part be an artifact of the difficulty in observing and identifying it, this moth does belong to a larger group of moths (flower moths or gems) that has low reproductive rates compared to other noctuid moths, has specialized and very restricted host plant dependencies, and comprises an inordinately large proportion of the rare Alberta moth fauna.

There are no obvious factors contributing to any significant decline in either Verna's flower moth population or its habitat. Large-scale changes in the cattle industry, either greatly increasing or greatly reducing grazing intensity in native pasture, could possibly result in a significant reduction in quantity and/or quality of Verna's flower moth habitat, as would the conversion of native pasture to other uses. The few available data are insufficient to provide much insight into population sizes or trends of Verna's flower moth at present. A significant amount of additional fieldwork and data collection is needed to provide insight into the population dynamics and habitat relationships of this interesting little moth. In addition to providing basic protection from industrial or other development for both the habitat and the moth at known sites, ongoing field surveys appear to be the most reasonable management option available at this time. 


\section{ACKNOWLEDGEMENTS}

Thanks are due to the following institutions and individuals who provided observations or information regarding Verna's flower moth: Lars Crabo (Noctuid moth specialist, Bellingham, WA); Chuck Harp (Heliothine specialist, Littleton, CO); Don Lafontaine (Canadian National Collection of Insects, Arachnids and Nematodes [CNC], Ottawa, ON); Marku Savalu (naturalist, Finland) and Chris Schmidt (CNC, Ottawa, ON). Assistance and companionship during various field surveys was provided by Chris Schmidt, Jason Dombroskie and David Lawrie. Thanks to Jim Troubridge (CNC, Ottawa) for providing information on how to locate these and other rare moths. Dorothy Fabijan (University of Alberta herbarium) kindly identified specimens of pussytoes. Dr. Felix Sperling and Danny Shpeley provided access to the University of Alberta Strickland Entomological Museum collections and facilities. Thanks are also due to several unnamed landowners who were kind enough to grant access to their property. Joel Nicholson (Alberta Sustainable Resource Development [SRD], Medicine Hat) provided insight into the loss of native grassland habitat in Alberta. Chris Schmidt and Greg Pohl (Canadian Forest Service, Edmonton) reviewed an early draft of the report.

COSEWIC provided funding for fieldwork and preparation of a national status report for Verna's flower moth in 2003. In 2007, SRD provided funding for additional field surveys in Alberta. Preparation of this report was funded by the Alberta Conservation Association and the Fish and Wildlife Division of SRD. 
Digitized by the Internet Archive in 2016 


\section{TABLE OF CONTENTS}

PREFACE iii

EXECUTIVE SUMMARY iv

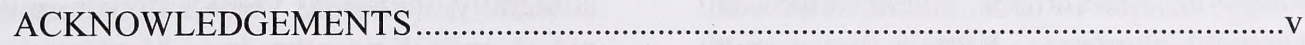

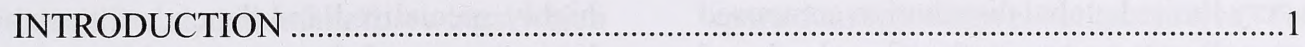

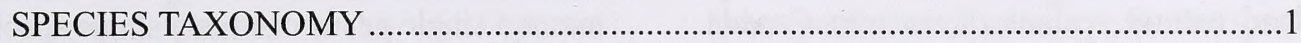

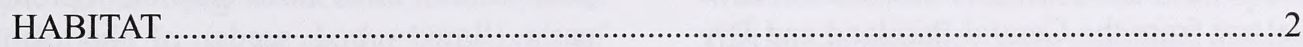

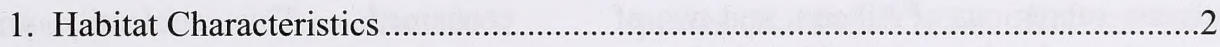

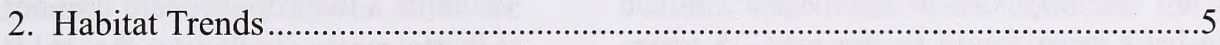

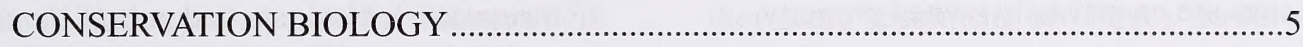

DISTRIBUTION

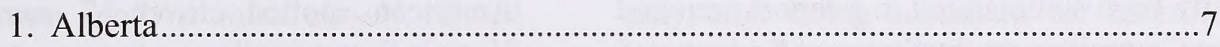

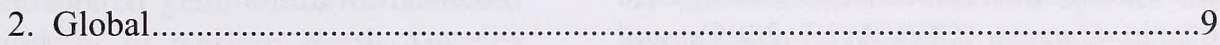

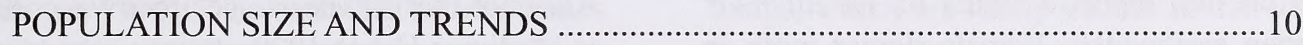

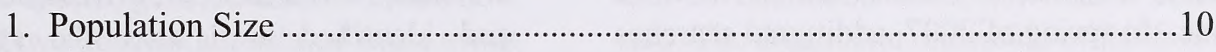

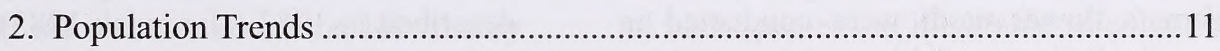

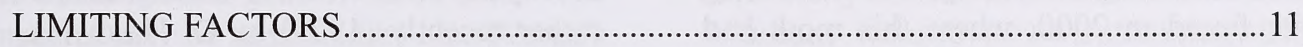

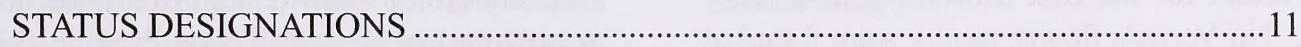

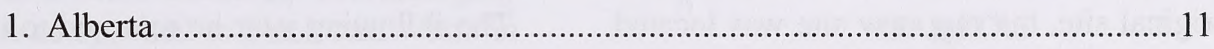

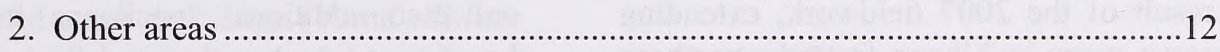

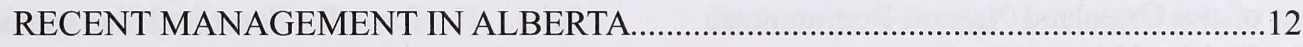

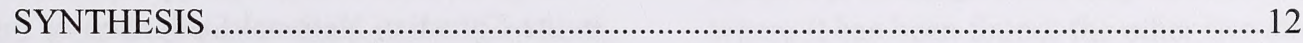

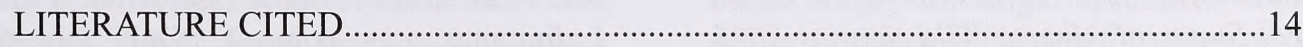

Appendix 1. Definitions of status ranks and legal designations .......................................16

\section{LIST OF FIGURES}

Figure 1. Alberta collection sites for Verna's flower moth ..............................................

Figure 2. Global distribution of Verna's flower moth ....................................................... 


\section{INTRODUCTION}

The purpose of this report is to compile and summarize all available information for Verna's flower moth (Schinia verna), with emphasis on information that can be used to determine its status in Alberta for conservation and management purposes. Verna's flower moth has a very limited global distribution composed of five collection sites in the Grassland and Parkland natural regions of western Canada. More than half of the known occurrences (three of five) are from the Central Parkland and Dry Mixedgrass subregions of Alberta, and two of these are the only sites where Verna's flower moths have been found in the past 25 years. Both sites are on privately owned property.

The global status of Verna's flower moth has recently been summarized in a report prepared for the Committee on the Status of Endangered Wildlife in Canada (COSEWIC 2005), and based on that report a status of Threatened* has been assigned to Verna's flower moth in Canada. In spring of 2007, additional searches for Verna's flower moth were conducted in Alberta, including revisiting and searching the site found in 2000 , where this moth had been found for the first time in Alberta since 1929. No Verna's flower moths were found at the original site, but one new site was located as a result of the 2007 fieldwork, extending the known range in Alberta from the northern portion of the Grassland Natural Region north into the Parkland Natural Region.

Verna's flower moth is not included in the General Status of Alberta Wild Species 2005, and is currently ranked $\mathrm{SU}$ (status undetermined/ uncertain) in Alberta by the Alberta Natural History Information Centre (ANHIC), because of the paucity of information that is available for this moth.

* See Appendix 1 for definitions of selected status designations.

\section{SPECIES TAXONOMY}

Verna's flower moth is a member of the subfamily Heliothinae (flower moths, gems, or flower gems) in the large cutworm or owlet moth family Noctuidae. Many species in the subfamily, including Verna's flower moth, are active only during the day. Most species are highly specialized and dependent upon a very limited range of plants as larval hosts, in many cases a single genus or even a single species of plant, and in most cases only the reproductive parts (flowers and seeds) of the plant are consumed. This subfamily consequently contains a disproportionate number of the rare Alberta moths, including the gold-edged gem (S. avemensis), black-spotted gem (S. honesta), rose-tinted gem (S. roseitincta), dark-banded flower gem (Melaporphyria immortua), American spotted clover ( $S$. nuchalis) and Verna's flower moth.

Although the first known specimen was collected at Medicine Hat in 1929, it was not recognized and identified until after the species was described in 1983 (Hardwick 1983). The first colony of Verna's flower moth was discovered rather recently (1979) by D. Hardwick, north of Glenboro in southwestern Manitoba in what is now part of Spruce Woods Provincial Park. The following year he returned to the site and collected additional specimens from which he obtained eggs and reared them through to adults. He formally described the species in 1983 (Hardwick 1983). The type specimens are in the Canadian National Collection of Insects and Arthropods Ottawa (Hardwick 1983, D. Lafontaine, pers. comm.). Only four single additional specimens have been found since, one at each of the four remaining known sites for Verna's flower moth. All populations are treated as belonging to a single species and no subspecies or lower taxonomic categories have been proposed.

Verna's flower moth is a small $(2.0 \mathrm{~cm}-2.2 \mathrm{~cm}$ wingspan) day-flying moth. The forewings are 
cream-white with dull maroon and olive-brown bands and two prominent spots of the same colours. The hindwings are white, broadly margined in black, with a prominent black central spot. It occurs with, and is extremely difficult to separate in the wild from, the related white-spotted midget (Eutricopis nexilis). These two species are most easily identified by examining the underside of the forewings, which are black and white in Verna's flower moth, but have rose-pink patches in the white-spotted midget. Both wing surfaces of both species are illustrated in colour on the University of Alberta virtual museum site (Anweiler 2003). Adults and larvae of Verna's flower moth are illustrated by Hardwick (1983) and adults and larvae of both species are also illustrated in colour in Hardwick (1996).

Verna's flower moth is most closely related to the black-spotted gem, which is restricted to the mountains of western North America (Hardwick 1996). The early life history stages of the black-spotted gem are unknown, and how closely the two species are related must await either more information about the life history of the black-spotted gem or DNA data. The two species may be separated by size (Verna's flower moth is smaller), wing colour (Verna's flower moth is more delicately coloured grey and maroon as opposed to black and white in black-spotted gem) and range (Verna's flower moth in prairie grasslands; black-spotted gem in mountain meadows).

In the past five years there have also been reports of what has tentatively been identified as Verna's flower moth from two locations in Washington State, USA (L. Crabo, pers. comm.; G. Anweiler, unpubl. data). However, owing to the very large disjunction between the Washington sites and the nearest known sites for Verna's flower moth, as well as the very different kinds of habitats where they have been found in Washington (sand dunes; mountain meadows), there are serious doubts about the identity of the Washington populations.
It cannot be overemphasized how difficult it is to identify a living Verna's flower moth in the field. It is a small, very active day-flying moth with a rapid buzzing bee-like, rather than moth-like, flight and the wings tend to be kept in motion even when the moth is visiting flowers to obtain nectar or deposit eggs. It has almost universally been mistaken for a whitespotted midget when encountered live. The first specimens collected by Hardwick were thought to be specimens of white-spotted midget, and it was not until he examined the dead specimens that he realized they were a new and undescribed species (Hardwick 1983). Both of the recent Alberta specimens were collected as whitespotted midgets, and again it was not realized they were specimens of Verna's flower moths until the specimens were examined in hand. The remaining two specimens were identified only after being submitted for identification by the collectors. The two species are best separated by examining the undersides of the wings, which are rarely visible in the wild but can be examined while alive in a collecting net. The diagnostic underside of the forewings of both species are illustrated in colour on the University of Alberta Strickland Entomological Museum website (www.entomology.ualberta. ca/searching.php).

\section{HABITAT}

1. Habitat Characteristics. - Information on the habitat occupied by Verna's flower moth in Canada is available from only three of the sites where it has been found; the other two sites are based simply on single specimens submitted without precise collection locations or habitat information. The three sites for which we have data are all in native grassland pastures being actively grazed by cattle, all with numerous populations of the larval host plant, Antennaria sp. (pussytoes; Asteraceae family), as well as a variety of spring-blooming native flowering plants, notably three-flowered avens (Geum triflorum), prairie crocus (Anemone patens), fleabane (Erigeron sp.) and mouse-eared 
chickweed (Cerastium arvense). All sites where Verna's flower moth has been collected are also proximate to major river systems, including the Assiniboine (Manitoba), South Saskatchewan (Saskatchewan, Alberta), Red Deer and Battle (Alberta) rivers.

The single factor known to be critical in Verna's flower moth habitat is a population of blossoming pussytoes, the only genus of plants used as a larval host by Verna's flower moths. Blossoming pussytoes plants, as opposed to non-flowering clones, are a prerequisite for hosting Verna's flower moths since only the flowering parts of the plant (flowers, seeds and seed receptacle) are consumed by Verna's flower moth larvae (Hardwick 1983). Pussytoes appear to require a release from overgrowth or heavy competition from other vegetation, in particular grasses, in order to produce mass blooming. This release from competition is provided in Verna's flower moth habitat by grazing cattle. Pussytoes colonies are often present as non-blooming or very sparsely blooming mats in ungrazed grasslands or grasslands with an overstory of lightly grazed grasses (COSEWIC 2005). The amount of annual precipitation may also influence the amount of annual blossoming of pussytoes (C. Schmidt, pers. comm.). Mass blooming after mechanical release is readily observed in parks and roadsides or other areas where native (or seeded) grasses are being mowed on a regular basis. The densest and most abundant patches of blossoming pussytoes observed during surveys in 2007 were in mowed sites in several regional parks and recreational areas (G. Anweiler, unpubl. data). However, such sites do not constitute useful Verna's flower moth habitat since recurrent mowing would destroy any larvae, and few other flowering plants suitable as nectar sources for adult moths are available in such sites.

The role of fire in creating or maintaining habitat is unknown, but is believed to be relatively unimportant. Suitable Verna's flower moth habitat, such as is found in wellgrazed pastures, has little grass cover to burn. Although COSEWIC (2005) suggested fire may also release pussytoes from overstory grasses in the absence of grazing, using fire to release pussytoes and promote blooming is not recommended, as it has been reported that small-leaved pussytoes (Antennaria parvifolia Nutt.) in Montana is killed by most fires (USDA Forest Service 2007). It is possible that the seeds of pussytoes may survive a low-intensity fire, allowing the plant to re-establish (and flower) after the disturbance, but this would need to be tested (J. Gould, pers. comm.; also see USDA Forest Service 2007).

Known Verna's flower moth habitat varies from site to site in topography, soils, floral components and intensity of grazing by cattle. In general, occupied Verna's flower moth habitat is located on poorer soils and/or on land with topography too steep or undulating to be suitable for cultivation. Relatively isolated and disjunct areas with apparently suitable habitat in Alberta (i.e., grazed pasture with an abundance of blooming pussytoes) occur in knob-andkettle end-moraine deposits in central Alberta (e.g., north of Stettler, the Pine Lake area, and the Rumsey Ecological Reserve). More extensive areas of somewhat interconnected habitat occur in native pasturelands in the Central Parkland and Dry Mixedgrass natural subregions of Alberta in and adjacent to the larger creek and river valleys, in particular along the Battle, Red Deer and South Saskatchewan rivers and their tributaries. These areas appear to have been left largely in a natural or seminatural state because of unsuitable topography for cultivation, and in some cases possibly also because of locally poor soils. Both the Verna's flower moth site near Alliance, $\mathrm{AB}$ and the site near Jenner, $A B$ are directly linked to the greater river valley systems. The upland pasture site at Alliance and the hillside pasture site at Jenner share a similar flora, with the main differences being the presence of aspen clones at Alliance but not at Jenner, and lighter sandy loam soil at 
Alliance and clay soils at Jenner (G. Anweiler, pers. obs.). The Manitoba site is located in the Assiniboine River drainage on relatively level topography on sandy soil (COSEWIC 2005). All three sites share many of the same springblossoming prairie plants (COSEWIC 2005; G. Anweiler, unpubl. data).

Moderate to heavy grazing on native grassland sites may be critical in maintaining suitable Verna's flower moth habitat. Extreme overgrazing, as occurred in the early part of this century in parts of eastern Alberta, tends to remove too much of the native plant cover, including pussytoes, even though the latter is reported to be unpalatable (USDA Forest Service 2007). Pussytoes has little food value; it is reported to be somewhat palatable to sheep, but is otherwise usually avoided by grazing animals (Tannas 2004). It seldom forms significant amounts of forage and what is produced is usually in mats below foraging levels. It also increases with and is an indicator of overgrazing (Tannas 2004).

Verna's flower moth has been found associated with several species of pussytoes and, although it is not known if all species of pussytoes are suitable hosts for Verna's flower moths, it is likely that more than one of the common widespread grassland species are used (i.e., Antennaria aprica Greene, A. neglecta Greene, and $A$. parvifolia Nutt.). At the type locality in Manitoba, Verna's flower moth was found using only one species of pussytoes, $A$. neglecta Greene (=howellii Greene,=neodioica Greene), as larval hosts, although a second species, A. aprica $\mathrm{E}$. Green, was also accepted when offered to larvae reared in captivity (Hardwick 1983). A. aprica is also present at the Jenner site (COSEWIC 2005). Both A. neglecta and $A$. aprica are widely distributed, although often local, over much of North America (Scoggan 1979). Pussytoes species have an extremely difficult and complex taxonomy, and identification of the various plants to species can be problematic (Chambers 1998). At the
Alliance site, what appeared to be two species of pussytoes were present where Verna's flower moth was found; however, specimens of both were subsequently identified as $A$. parvifolia (Nutt.) (D. Fabijan, pers. comm.). These two forms of A. parvifolia occurred in mixed patches. The one with larger, greener basal leaves had already finished blooming with the flower heads expanded and dry; the other, with smaller greyer leaves was in fresh bloom and was the form that Verna's flower moth was visiting (G. Anweiler, pers. obs.). The larval period of Verna's flower moth is timed to coincide with blossoming and seed set of larval host species of pussytoes, thus some species at a site may not be suitable hosts (C. Schmidt, pers. comm.).

Small-leaved pussytoes (A. parvifolia) is generally found on open plains and prairie, in open forest, dry meadows and pastures, and along roadsides. It exhibits good growth on gentle slopes, but does not grow well on steep slopes. It grows best on loam, clay-loam and clay-textured soils. Growth is poor on gravel, sand, and dense clay (USDA Forest Service 2007).

At all sites where Verna's flower moth was found, it was flying together with another superficially similar, but more widespread and common pussytoes-feeding flower moth, the white-spotted midget (Hardwick 1983; COSEWIC 2005; G. Anweiler, unpubl. data). The presence of white-spotted midgets at many sites where Verna's flower moth was NOT found suggests that white-spotted midgets may have broader or slightly different habitat requirements than Verna's flower moths, and their presence at a site may not necessarily be an indication of suitable Verna's flower moth habitat. However, the absence of the more common white-spotted midgets at a site appears to serve as a good indicator that the habitat is unsuitable for Verna's flower moth or that the timing of the survey may be off. 
2. Habitat Trends. - There is little doubt that native grassland pasture habitat in the Parkland Natural Region and northern portion of the Grassland Region in Alberta (and elsewhere) have been reduced in the past and continue to decrease in area. Every piece of native grassland that is plowed or otherwise converted from the native state is essentially of no use to Verna's flower moth and other wild species that rely on native grassland habitat. Only about $25 \%$ of the original Canadian prairie habitat still supports native vegetation (Statistics Canada 1992). That being said, the rate at which conversion of native habitat for agriculture is happening today has slowed, as most of the land suitable for crops has already been converted, and what remains is usually marginal land. The amount of land in Alberta reported as native land used for pasture declined by about $30000 \mathrm{ha} / \mathrm{yr}$ or about $0.5 \%$ a year between the years 2001 and 2006 (Statistics Canada 2007). However, conversion of native grassland considered marginal for agriculture is continuing, because of urbanization (acreage development), oil and gas exploration and extraction, recreational uses, gravel or sand extraction, transportation corridors and other types of development ( $\mathrm{J}$. Nicholson, pers. comm.). So some suitable habitat for Verna's flower moth is undoubtedly being lost.

Both economic and climatic factors may have long-term deleterious impacts on habitat of Verna's flower moth. Overgrazing of native pastures during the extreme drought conditions in east-central Alberta in recent years resulted in some native pasture being critically overgrazed to the point where essentially all native species were replaced by monocultures of weedy species (e.g., pasture sage, Artemesia frigida Willd.). Changes in the economics of the cattle industry, such as what resulted from the recent outbreak of bovine spongiform encephalopathy (BSE) in cattle, may result in smaller numbers of cattle being produced and some areas of native grassland being underutilized or converted to other uses.
In general, it appears that there is an abundance of suitable habitat for Verna's flower moth available in the Parkland and northern Grassland natural regions of Alberta, of which only a very small proportion (perhaps less than $1 \%$ ) has been surveyed for this moth. Where suitable habitat has been surveyed, however, the moth has been very rarely encountered. There is no evidence suggesting that habitat is limiting populations of Verna's flower moth. Much more work is needed in order to identify the precise habitat elements that define quality habitat for this moth, and what factors, if any, are limiting populations at present.

\section{CONSERVATION BIOLOGY}

Verna's flower moth is a small single-brooded (one generation per year) diurnal moth that is totally dependent upon a single genus of plants, Antennaria or pussytoes species, for reproduction. It has a typical four-stage lepidopteran life cycle of egg, larva, pupa and adult, and overwinters in the pupal stage in or on the soil. The active growth period of the life cycle of Verna's flower moth (egg to pupation) is very short, taking only about three weeks (average of 17.1 days in the laboratory). Most of its life, approaching 11 or 12 months, is passed essentially dormant as a pupa in a cell in or on the soil (Hardwick 1983). The adult moths are short-lived. Hardwick (1996) found that adult flower moths lived no more than a week in captivity. Persson (1972) reported that longevity in noctuid moths was temperature dependent, and that in spring adult moths lived for an average of 11.8 days, in summer for 4.8 days. Cooler spring weather reduced activity periods and promoted longer life, whereas hot summer temperatures resulted in increased activity, desiccation and a shortened life span. Although there are no longevity data for Verna's flower moth, it is a spring-flying noctuid and an adult life expectancy of 1-2 weeks is most likely. 
The life cycle is intimately linked with the blooming cycle of the host plant. Single eggs are deposited deeply within the flowering head of the pussytoes plant, and hatch within three days. The newly hatched larva burrows immediately into the seed layer of the blossom where it feeds on the developing seeds and receptacle. The larva passes through five instars prior to pupation.

Once mature, the larva departs from the plant and digs a short tube at or just below the soil surface; at the end of this tube, it prepares a cell in which it pupates. There it remains dormant until the host plant blooms again the following spring. Nothing is known regarding mortality factors or rates that occur during this period. However, it is possible that excessive grazing can compact soil and destroy pupating Verna's flower moth pupa at and just below the soil surface, although this has never been demonstrated.

The egg of Verna's flower moth is unusually large and likely relatively few are produced. The closely related white-spotted flower moth, which feeds on the same host and has a parallel life history, also produces unusually large eggs. Females of wild-caught white-spotted midgets produced only 7-10 eggs in captivity, an extremely low fecundity rate for owlet moths (Hardwick 1970). A similar rate can be expected for Verna's flower moth.

Newly hatched larvae of Verna's flower moths are very cannibalistic, as well as predatory on larvae of white-spotted flower moths. A number of dissected flower heads were found to contain remains of both Verna's flower moth and white-spotted flower moth larvae, along with a healthy first or second instar larva of a Verna's flower moth (Hardwick 1983). This interesting and unusual life-history trait may confer a competitive advantage on Verna's flower moths, particularly if the quantity or quality of food is a limiting factor. It is unknown if white-spotted midget larvae also prey on Verna's flower moth larvae. First instar larvae hatching in a flower head already occupied by a Verna's flower moth larva were observed to abandon the occupied head and seek one that was unoccupied. The survival rate of these larvae was thought to be low, because in most cases observed the larvae were unable to enter new heads and fell from the host plant. Second instar larvae were able to migrate from one flower head to another, and once the first instar was completed they were observed to regularly move to another, entering from the top. Third and later instar larvae often tied adjacent heads together to form a protective shelter in which they fed. Prior to moulting in these later instars, they form a nest out of floral parts in which they rest until the moult is completed. Last instar larvae feed on the base of the flower head from an exposed position on the stem below (Hardwick 1983).

No other mortality agents are known for Verna's flower moth, but Lepidoptera in general suffer high mortality during the larval stages as a result of predation by birds, predatory invertebrates including parasitic flies and wasps, and fungal, bacterial and viral pathogens. Concealment in flower heads during feeding may be a predator/ parasitoid avoidance strategy in flower moths (Hardwick 1996).

Pussytoes tend to bloom en masse, but the timing can vary by several weeks from year to year (G. Anweiler, pers. obs.). The close link and dependency of Verna's flower moth to the flowering cycle of the host plant suggests that the environmental factors triggering blooming also trigger emergence of Verna's flower moth adults. This has implications for surveys for the moth; the flight period is a relatively short one and can vary by several weeks from year to year (Hardwick 1983; G. Anweiler, pers. obs.), and to be effective, surveys must be timed to coincide with the flight period.

Although the dispersal ability of Verna's flower moth is unknown, adults are strong, fast fliers. It is possible that larger areas of continuous or 
semi-continuous suitable habitat, such as those that occur in and adjacent to drainages, may be important to maintaining populations over the long term. Although adult Verna's flower moths may be capable of crossing wide areas of unsuitable habitat, possibly many kilometres in extent, there would be a greater likelihood of encountering suitable habitat and, more importantly, other individuals of their species with which to mate in areas with continuous or semi-continuous habitat. Unfortunately, data on long-distance dispersal and survival are very difficult to obtain and are essentially non-existent for flower moths. Generalist feeders, like a related Heliothine moth, the corn earworm (Helicoverpa zea Boddie), are known to undergo long-distance dispersal, having reached even Hawaii in recent years (Hardwick 1996). However, long distance dispersal must be much more hazardous and much less successful for specialist species, such as Verna's flower moths, which must locate suitable habitat with suitable host plants of a single species or genus.

The host plants of Verna's flower moth are widespread plants found in grasslands throughout much of North America. Because pussytoes species, including the only confirmed host for Verna's flower moths, have such a broad range and occur in several ecoregions outside of the prairies, Verna's flower moth is unlikely to be limited by the distribution of the host plant. It is more likely that a combination of factors such as host plant availability, soil substrate type and adult nectar sources limit distribution (C. Schmidt, pers. comm.).

Although adult Verna's flower moths have been observed feeding on nectar from blossoms of pussytoes (G. Anweiler, unpubl. data), it is not known whether or not other species of spring-flowering plants are needed to provide a supplemental nectar source. The related gold-edged gem uses its host sunflower plant as a nectar source, but also avidly obtains nectar from other nearby unrelated species (G. Anweiler, pers. obs.).
The impact of agricultural chemicals on Verna's flower moths is unknown. Applications of herbicides and insecticides in occupied habitat would almost certainly have a negative impact on Verna's flower moths, along with other insects. There are few data on the extent, if any, that insecticides are applied in actively grazed native grassland pasture.

\section{DISTRIBUTION}

1. Alberta. - Based on the current state of knowledge, the distribution of Verna's flower moth in Alberta is probably quite fragmented, although perhaps less so along drainages where ribbons of unbroken native grassland exist. However, even in such habitat, grazing is rarely occurring throughout, with ungrazed blocks (and hence, unsuitable habitat) fragmenting the distribution.

Single specimens of Verna's flower moth have been collected at three sites in Alberta (Figure 1). One recent site (collected in 2007) is near Alliance, by the southern edge of the Central Parkland Subregion in the Parkland Natural Region. Another recent site (collected in 2000) is near Jenner in the Dry Mixedgrass Subregion of the Grasslands Natural Region. Given the localized geographic distribution of these recently recorded flower moth colonies, these records most likely represent two extant colonies rather than dispersing individuals caught by chance. The third site is a historical one in Medicine Hat, also located in the Dry Mixedgrass Subregion. The percent of the global population occurring in Alberta ( 3 of the 5 occurrences) is likely somewhere between $33 \%$ and $50 \%$.

The known Alberta population is extremely fragmented, with the two recent colonies about $185 \mathrm{~km}$ apart, and the historical site $75 \mathrm{~km}$ from the nearest of the two, all located along different river valleys. There are no data documenting the ability of Verna's flower moth to colonize. Most Schinia species are strong 


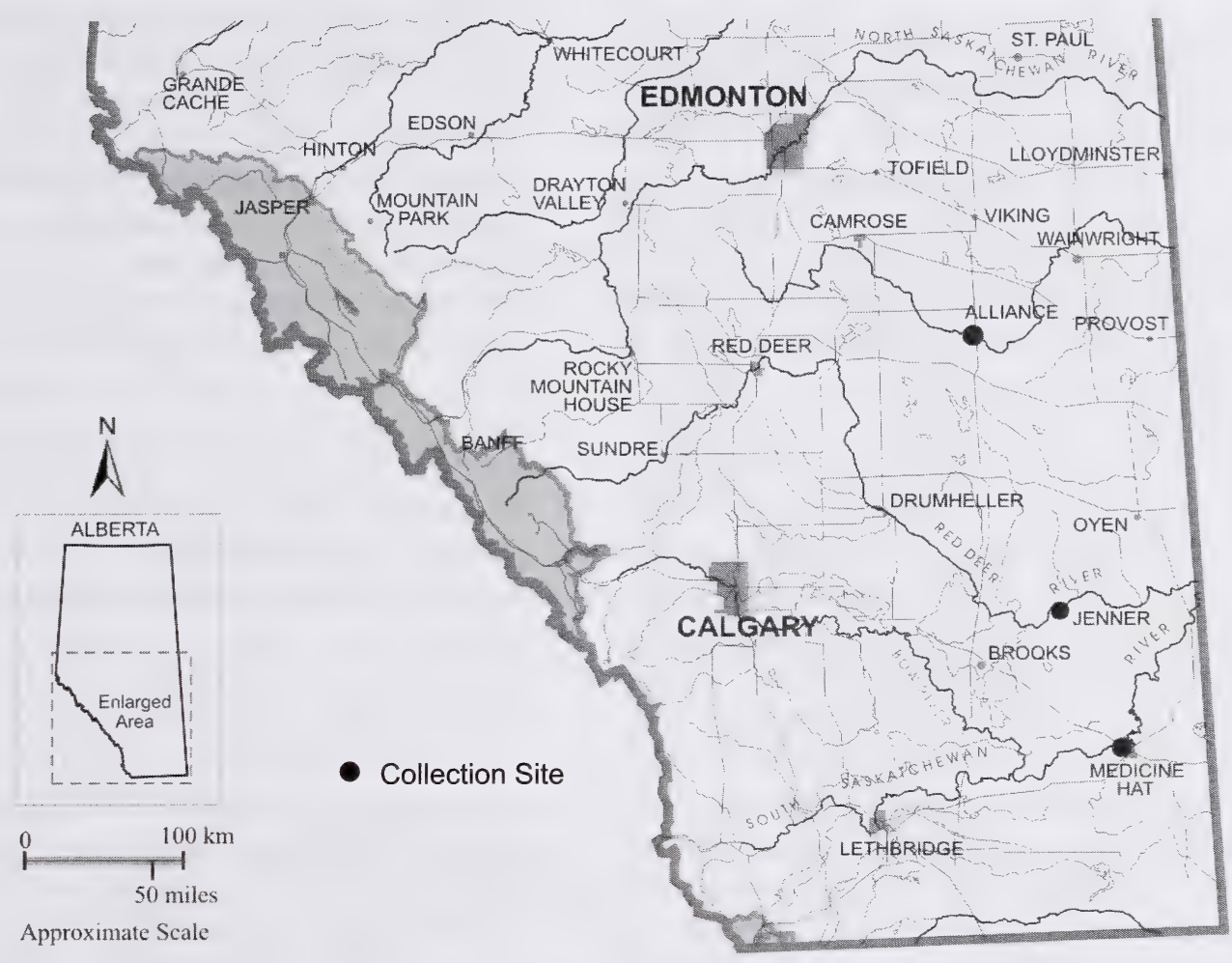

Figure 1. Alberta collection sites for Verna's flower moth.

fliers with a rapid, buzzing flight (C. Schmidt, unpubl. data; G. Anweiler, pers. obs.); strong rapid flight would facilitate colonization of host plant patches spatially separated by unsuitable habitat. Although Schinia species may have the ability for rapid dispersal, many species exhibit high site and host plant fidelity, and are rarely observed away from the immediate vicinity of the host plants (Hardwick 1996, Swengel and Swengel 1999). There is little chance of movement by individuals of Verna's flower moths between the known Alberta sites, since each site is located in a different major drainage system.
A realistic extent of occurrence figure for Alberta is impossible to determine based on the very limited available data. The three sites where Verna's flower moth has been found in Alberta lie along an almost straight line approximately $285 \mathrm{~km}$ long.

The area of occupancy calculated using a 2-km x 2-km square for each data point produces a figure of $12 \mathrm{~km}^{2}$. A more realistic estimate would be somewhere between $20 \mathrm{~km}^{2}$ and $100 \mathrm{~km}^{2}$, considering the amount of apparently suitable but unsurveyed habitat that is present along the drainages where the occupied sites occur, combined with the difficulty in detecting 
Verna's flower moths, even in occupied habitat.

2. Global. - Verna's flower moth is known only from the Canadian prairie provinces, in southwestern Manitoba (one colony with a number of individuals), south-central Saskatchewan (one single specimen record) and southeastern Alberta (1 historical specimen; 2 recent observations, each of a single live moth) (Figure 2). There are also recent unconfirmed reports of Verna's flower moths from two locations in the state of Washington, USA. However, there is evidence suggesting these records may refer to a closely related, but undescribed, species instead of Verna's flower moth, and the presence of Verna's flower moth in Washington still needs to be confirmed (L. Crabo, pers. comm.; G. Anweiler, unpubl. data).
The global extent of occurrence for Verna's flower moth is approximately $140000 \mathrm{~km}^{2}$ $150000 \mathrm{~km}^{2}$. However, the area of occupancy within this area is a fragment of that total. Using a 2-km x 2-km grid per occurrence method (adapted from IUCN 2001), the global area of occupancy, including both current and historical occurrences, is approximately $20 \mathrm{~km}^{2}$. There are too few data to provide a realistic figure for area of occupancy. However, this figure is based on the number of locations where Verna's flower moth has actually been located; when one considers the amount of suitable habitat that has not been surveyed and the difficulty in locating the moth even when it is present, an estimate of between $100 \mathrm{~km}^{2}$ and $1000 \mathrm{~km}^{2}$ is suggested as being more reasonable.

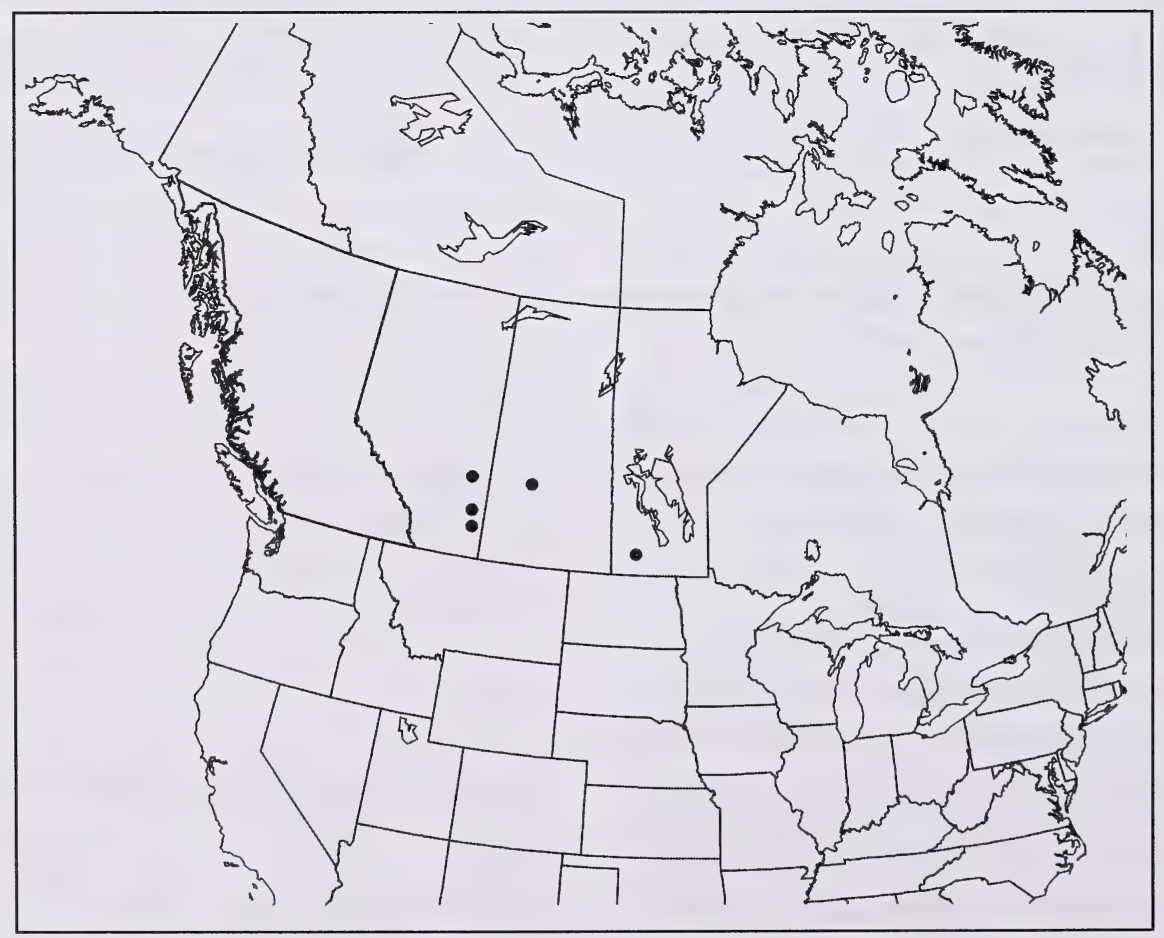

Figure 2. Global distribution of Verna's flower moth. 


\section{POPULATION SIZE AND TRENDS}

1. Population Size. - Verna's flower moth is known from only five sites globally, three of which are in Alberta. At all but one site (Glenboro, MB) only a single specimen has been collected. Given the localized geographic distribution of flower moth colonies in general, each of these records most likely represented a local population rather than a dispersing individual encountered by chance.

Nevertheless, nothing concrete can be stated regarding population sizes or trends based on such limited data. The five observations are spread over a period of almost 80 years, with all but the first in the last 40 years. Observations at these five sites were made in 1929 (Medicine Hat, AB), 1979-1980 (Glenboro, MB), 1980 (Saskatoon, SK), 2000 (Jenner, AB) and 2007 (Alliance, AB). Although few observations would be expected of a truly rare species, a minimum standard of a two-hour search of suitable habitat under suitable conditions (e.g., $60^{\circ} \mathrm{C}$ or higher and sunny) would reasonably be expected to locate more than one or two specimens if a population is present. It is also possible that once a better understanding of the precise habitats occupied by Verna's flower moths is available, the moth will be found to be more common and widespread. This has been demonstrated repeatedly by J. Troubridge for numerous species of noctuid moths thought to be rare, but found to be localized (but far from rare) once the correct habitat was identified (J. Troubridge, pers. comm.).

Although D. Hardwick found a thriving population (16 specimens were collected at the site over a seven-day period) at the Glenboro site in both 1979 and 1980 (Hardwick 1983), a visit to the site in 2003 failed to locate the moth (COSEWIC 2005). The site at Jenner, where a single Verna's flower moth was collected in 2000, was revisited and searched in 2003, 2004, 2005 and 2007, also without success (COSEWIC 2005; G. Anweiler, unpubl. data).
Most of the potential habitat for Verna's flower moth remains to be surveyed. It is highly probable that the general decrease in native grassland has resulted in a corresponding decrease in size and number of populations.

Surveys in 2003 and 2004 of localities at which Verna's flower moth had previously been recorded failed to locate extant populations. Although patches of the larval host plant are relatively conspicuous and can be locally abundant, the lack of observations of Verna's flower moths during searches of these patches suggests that other less obvious environmental factors may determine the presence and abundance of Verna's flower moths. However, the paucity of records and the recent discovery of this species suggest that Verna's flower moth is truly rare. Data on the population dynamics of flower moth species in general are lacking; however, Swengel and Swengel (1999) show that population levels of Schinia indiana (Smith) varied substantially over a five-year period. It is possible that Verna's flower moth exhibits similar population dynamics, making detection in years of low population levels even more improbable. Many species of heliothines have the ability to remain in the pupal stage for a number of years before emerging; this ability is particularly well-developed in species indigenous to arid areas (Hardwick 1996). More field surveys over multiple years, in order to detect potential population fluctuations, are needed before population sizes can be evaluated.

It cannot be overemphasized that Verna's flower moth is a very difficult moth to locate and identify in the field. Unlike nocturnal moths, which in most cases can be easily sampled using a variety of light traps, Verna's flower moth must be searched for during the day by eye and with net. Concerted and repeated surveys in potential habitat throughout the known adult flight period are needed before much can be said with any confidence about population sizes and trends. Most likely an ongoing awareness 
of the possible presence of this little moth and its habits will slowly add to our knowledge and database, leading to a more comprehensive and reliable picture of the status of Verna's flower moth in Alberta.

2. Population Trends. - The limited data can provide little insight into population trends. What can be said is that, in spite of the insect collecting that has taken place in the prairie provinces of Canada almost continuously over the past 100 years, Verna's flower moth has been knowingly encountered at only five sites. It is illustrative that it was not found in the Spruce Woods Provincial Park area prior to 1979 , even though Norman Criddle was a resident collector in the area for some 30 years during the early part of the last century.

The first known specimen was a single specimen collected by F.S. Carr in the Medicine Hat, Alberta area in 1929. It was not collected again until 1979 when D. Hardwick discovered the colony in Manitoba. He returned the following year and collected additional specimens and worked out the life history. A single specimen was collected in the Saskatoon, Saskatchewan area in 1980 as well. The next specimen was collected near Jenner, Alberta in 2000, and the last one near Alliance in 2007. Thus it appears this moth has been present for many years, but always in small numbers.

Sites where Verna's flower moths have been found in the more recent past (i.e., in the last 30 years) should be visited and searched under favourable conditions (warm and sunny) at least twice, and preferably three times, each season at about one-week to 10-day intervals. Site visits should begin when the first pussytoes are blooming. This protocol should be conducted over a period of at least 3-5 years (or longer, if necessary, to ensure that varying annual moisture conditions are represented) before concluding the site is no longer supporting the moth.

\section{LIMITING FACTORS}

Nieminen (1996) has pointed out that the pattern of population extinction in moths is affected by host plant characteristics rather than by the characteristics of the moths themselves; furthermore, moths that feed on a single host species are more likely to suffer extirpation than are species that feed on a wider range of hosts, as are species that occur in highly fragmented, disjunct populations. Verna's flower moth is thus a highly vulnerable species, being both monophagous and having a highly fragmented population.

No other specific limiting factors for Verna's flower moth have been identified. Potential threats include anything that adversely affects the health and abundance of the larval host plants. Loss or fragmentation of habitat as a result of agricultural tillage and severe overgrazing would result in loss of native plant cover, including larval and adult food plants. The host plants are also intolerant of a thick vegetation overstory, so large, invasive plant species could also be detrimental. Since the pupae spend almost 11 months in a shallow underground chamber, soil trampling by livestock in heavily grazed pastures may be a limiting factor. Less severe disturbances, such as fires and haying, would have the greatest potential impact during the flowering and seeding stage of pussytoes, when larvae and eggs are developing. Depending on pupation depth and fire intensity, Verna's flower moths may be able to survive fire events during the pupal stage.

\section{STATUS DESIGNATIONS*}

1. Alberta. - Since Verna's flower moth was not described until 1983, there are no historical designations. It is not included in Alberta's

\footnotetext{
* See Appendix 1 for definitions of selected status designations.
} 
Wildife Act, or in the General Status of Alberta Wild Species 2005 (Alberta Sustainable Resource Development 2007). It is ranked as Status Uncertain (SU) by the Alberta Natural Heritage Information Center (ANHIC, pers. comm.)

2. Other Areas. - Verna's flower moth has not been assigned a national general status in Canada (Canadian Endangered Species Conservation Council [CESCC] 2006). It was assigned Threatened status by COSEWIC (COSEWIC 2005 and 2007), but has not been added to Schedule 1 of the federal Species at Risk Act (SARA), because it was referred back to COSEWIC by the Minister of Environment because of perceived deficiencies in the data on species distribution, abundance, range, threats and suitable habitat (Canada Gazette 2006). COSEWIC has since re-confirmed the status of Threatened and has re-submitted it to the Minister for listing under SARA as such. A final decision on whether or not Verna's flower moth will be listed under SARA is expected in late 2008 .

NatureServe (2007) lists it globally as GU (global status uncertain because of low search effort or cryptic nature of the element; more data needed). The Saskatchewan Conservation Data Centre ranks Verna's flower moth as SH (historical occurrence) (Saskatchewan Conservation Data Centre 2007); Manitoba lists it as SNA (Status Not Applicable) (Manitoba Conservation Data Centre 2001).

Verna's flower moth is not known to occur in any other jurisdictions.

\section{RECENT MANAGEMENT IN ALBERTA}

So few data are available for this moth in Alberta that management specifically directed for it has been precluded. The only justifiable management at this time appears to be to provide funding for data collection, especially fieldwork directed to locating extant populations in Alberta. In particular, more extensive and intensive surveys could be carried out in native pasturelands along the three major river systems in southern Alberta (Battle, Red Deer and South Saskatchewan), and especially along the lower Red Deer and Battle River valleys, where Verna's flower moths have been found in recent years. Given the difficulty of finding the moth, surveying for locations of the known hosts would be a good starting point. It would also be of value to identify and confirm the taxonomic status of the species of Antennaria present at the two known Verna's flower moth sites in Alberta.

In 2003, COSEWIC commissioned a status report for Verna's flower moth and provided funding for limited survey work, including in southern Alberta. This resulted in COSEWIC assigning Verna's flower moth a status of Threatened in 2005.

In 2007, Alberta Sustainable Resource Development provided funding for additional field surveys for Verna's flower moth in southern Alberta, and together with the Alberta Conservation Association supported the preparation of this status report.

\section{SYNTHESIS}

Verna's flower moth is a recently described, small, day-flying noctuid moth. It is known globally from only five locations in the Parkland and Grassland natural regions of the southern prairie provinces of Canada. Three of these sites are located in Alberta, and two of the Alberta sites are the only places where Verna's flower moth has been found in the past 24 years anywhere. Verna's flower moth habitat consists of native grasslands that are being actively grazed by cattle; undisturbed native grasslands do not appear to be favoured by this species.

Verna's flower moth is extremely difficult to recognize in the wild, which greatly complicates efforts to find and obtain information that would 
assist in evaluating its management needs. This, combined with the fact that it appears to be a rare species, makes gathering the data needed to determine population size and trend a slow and frustrating exercise.

There are no obvious imminent or other threats to this moth at present. The life history of Verna's flower moth leaves it vulnerable to extirpation (Nieminen 1996). Current grazing practices in
Alberta appear to provide favourable habitat that is supporting populations of Verna's flower moths. The only practical management options that appear to exist at present are to provide basic protections for known sites, and to support additional and more intensive field surveys in order to provide a more complete picture of the status and ecology of this interesting moth in Alberta. 


\section{LITERATURE CITED}

Alberta Natural Heritage Information Centre (ANHIC). 2007. Rank definitions. Parks and Protected Areas Division, Alberta Community Development. URL: http://www.cd.gov.ab.ca/ preserving/parks/anhic/definitions.asp [Updated 15 December 2006].

Alberta Sustainable Resource Development. 2007. The General Status of Alberta Wild Species 2005. URL: http://www. srd.gov.ab.ca/fw/wildspecies/index. htm [Updated January 2007.

Anweiler, G. 2003. Species page - Schinia verna. University of Alberta E.H. Strickland Entomological Museum.

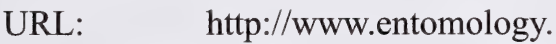
ualberta.ca/searching_species_details. php? $=288$

Canada Gazette. 2006. Government of Canada. Vol. 140. No. 18. Sept. 6, 2006. URL: http://www.sararegistry. gc.ca/virtual_sara/files/orders/ g2\%2D14018iii\%5Fe\%2Epdf

Canadian Endangered Species Conservation Council (CESCC). 2006. Wild Species 2005: The General Status of Species in Canada. http://www.wildspecies. $\mathrm{ca} /$ wildspecies2005/index.cfm?lang $=\mathrm{e}$

COSEWIC 2005. COSEWIC assessment and status report on the Verna's flower moth Schinia verna in Canada. Committee on the Status of Endangered Wildlife in Canada. Ottawa. vi +19 pp. (www. sararegistry.gc.ca/status/status_e.cfm).

COSEWIC. 2006. Definitions and Abbreviations. Committee on the Status of Endangered Wildlife in Canada. URL: http://www.cosewic. gc.ca [Updated April 2006].
COSEWIC. 2007. Database. Committee on the Status of Endangered Wildlife in Canada. URL: http://www.cosewic. gc.ca [Updated 2007-09-05].

Chambers, K. L. 1998. "Cherchez les hommes" (in Antennaria, boys are a minority). Oregon Flora Newsletter, Vol. 4 (3). Oregon State University.

Hardwick, D.F. 1970. The life history of Eutricopis nexilis (Noctuidae). J. Lep. Soc. 24:151-156.

Hardwick, D.F. 1983. A new species of Schinia (Noctuidae) from southern Manitoba and Saskatchewan with descriptions of its life history. J. Lep. Soc. 37:18-23.

Hardwick, D.F. 1996. A Monograph to the North American Heliothentinae (Lepidoptera: Noctuidae). Published privately. $281 \mathrm{pp}$.

IUCN. 2001. IUCN Red List Categories and Criteria: Version 3.1. IUCN Species Survival Commission. IUCN, Gland, Switzerland and Cambridge , UK. Available at http://www.iucnredlist. org/

Manitoba Conservation Data Centre. 2001. Species and Plant Community Database Search. URL: http://web2. gov.mb.ca/conservation/cdc/

National Research Council. 1995. Science and the Endangered Species Act. National Academy Press, Washington, DC. 271 pp.

NatureServe. 2007. NatureServe Explorer: an online encyclopedia of life [web application]. Version 6.2. Arlington, Virginia, USA: NatureServe. URL: http://www.natureserve.org/explorer [Updated 28 June 2007]. 
Nieminen, M. 1996. Risk of population extinction in moths: effect of host plant characteristics. Oikos 76:475-484

Persson, B. 1972. Longevity of Noctuid moths in relation to certain day-time weather factors. Oikos 23: 394-400. Copenhagen.

Saskatchewan Conservation Data Centre. 2007. Species Lists. URL: http:// www.biodiversity.sk.ca/FTP.htm [Last Updated: June 2007].

Scoggan, H.J. 1979. The Flora of Canada. Part 4. Dicotyledoneae (Loasaceae to Compositae). National Museum of Natural Sciences, National Museums of Canada, Ottawa. Pp 1117-1711.
Statistics Canada. 1992. 1991 Census of Agriculture. Ottawa.

Statistics Canada. 2007. http://www.statcan. $\mathrm{ca} /$ english/agcensus2006/index.htm

Swengel, A.B. and S.R. Swengel. 1999. Observations on Schinia indiana and Schinia lucens in the Midwestern UnitedStates(Lepidoptera:Noctuidae). Holarctic Lepidoptera 6(1):11-21.

Tannas, K. 2004. Common Plants of the Western Rangelands. Vol. 3: Forbs. Olds College and Alberta Agriculture, Food and Rural Development.

USDA Forest Service. 2007. Fire Effects Information System. (www.fs.fed. us/database/feis/). Accessed Sept. 7, 2007 
Appendix 1: Definitions of status ranks and legal designations.

A. The General Status of Alberta Wild Species 2005 (after Alberta Sustainable Resource Development 2007)

\begin{tabular}{|c|c|c|}
\hline 2005 Rank & 1996 Rank & Definitions \\
\hline At Risk & Red & $\begin{array}{l}\text { Any species known to be At Risk after formal detailed status } \\
\text { assessment and designation as Endangered or Threatened in } \\
\text { Alberta. }\end{array}$ \\
\hline May Be At Risk & Blue & $\begin{array}{l}\text { Any species that may be at risk of extinction or extirpation, and is } \\
\text { therefore a candidate for detailed risk assessment. }\end{array}$ \\
\hline Sensitive & Yellow & $\begin{array}{l}\text { Any species that is not at risk of extinction or extirpation but may } \\
\text { require special attention or protection to prevent it from becoming at } \\
\text { risk. }\end{array}$ \\
\hline Secure & Green & Any species that is not At Risk, May Be At Risk or Sensitive. \\
\hline Undetermined & $\begin{array}{l}\text { Status } \\
\text { Undetermined }\end{array}$ & $\begin{array}{l}\text { Any species for which insufficient information, knowledge or data } \\
\text { is available to reliably evaluate its general status. }\end{array}$ \\
\hline Not Assessed & $\mathrm{n} / \mathrm{a}$ & Any species that has not been examined during this exercise. \\
\hline Exotic/Alien & $\mathrm{n} / \mathrm{a}$ & Any species that has been introduced as a result of human activities. \\
\hline Extirpated/Extinct & $\mathrm{n} / \mathrm{a}$ & $\begin{array}{l}\text { Any species no longer thought to be present in Alberta (Extirpated) } \\
\text { or no longer believed to be present anywhere in the world (Extinct). }\end{array}$ \\
\hline Accidental/Vagrant & $\mathrm{n} / \mathrm{a}$ & $\begin{array}{l}\text { Any species occurring infrequently and unpredictably in Alberta, } \\
\text { i.e., outside its usual range. }\end{array}$ \\
\hline
\end{tabular}

\section{B. Alberta Species at Risk Formal Status Designations}

Species designated as Endangered under Alberta's Wildlife Act include those listed as Endangered or

Threatened in the Wildlife Regulation (in bold).

\begin{tabular}{|l|l|}
\hline Endangered & A species facing imminent extirpation or extinction. \\
\hline Threatened & A species likely to become endangered if limiting factors are not reversed. \\
\hline $\begin{array}{l}\text { Species of } \\
\text { Special Concern }\end{array}$ & $\begin{array}{l}\text { A species of special concern because of characteristics that make it particularly sensitive to } \\
\text { human activities or natural events. }\end{array}$ \\
\hline Data Deficient & A species for which there is insufficient scientific information to support status designation. \\
\hline
\end{tabular}

\section{Committee on the Status of Endangered Wildlife in Canada (after COSEWIC 2006)}

\begin{tabular}{|l|l|}
\hline Extinct & A species that no longer exists. \\
\hline Extirpated & A species that no longer exists in the wild in Canada, but occurs elsewhere. \\
\hline Endangered & A species facing imminent extirpation or extinction. \\
\hline Threatened & A species that is likely to become endangered if limiting factors are not reversed. \\
\hline Special Concern & $\begin{array}{l}\text { A species that may become threatened or endangered because of a combination of } \\
\text { biological characteristics and identified threats. }\end{array}$ \\
\hline Not at Risk & $\begin{array}{l}\text { A species that has been evaluated and found to be not at risk of extinction given the } \\
\text { current circumstances. }\end{array}$ \\
\hline Data Deficient & $\begin{array}{l}\text { A category that applies when the available information is insufficient to (a) resolve a } \\
\text { wildlife species' eligibility for assessment, or (b) permit an assessment of the wildlife } \\
\text { species' risk of extinction. }\end{array}$ \\
\hline
\end{tabular}


D. Heritage Status Ranks: Global (G), National (N), Sub-national (S) (after Alberta Natural Heritage Information Centre 2007, NatureServe 2007)

\begin{tabular}{|l|l|}
\hline G1/N1/S1 & $\begin{array}{l}5 \text { or fewer occurrences or only a few remaining individuals. May be especially vulnerable } \\
\text { to extirpation because of some factor of its biology. }\end{array}$ \\
\hline G2/N2/S2 & $\begin{array}{l}6 \text { to } 20 \text { or fewer occurrences or with many individuals in fewer locations. May be especially } \\
\text { vulnerable to extirpation because of some factor of its biology. }\end{array}$ \\
\hline G3/N3/S3 & $\begin{array}{l}21 \text { to } 100 \text { occurrences; may be rare and local throughout its range, or in a restricted range } \\
\text { (may be abundant in some locations). May be susceptible to extirpation because of large- } \\
\text { scale disturbances. }\end{array}$ \\
\hline G4/N4/S4 & Typically > 100 occurrences. Apparently secure. \\
\hline G5/N5/S5 & Typically > 100 occurrences. Demonstrably secure. \\
\hline GX/NX/SX & Believed to be extinct or extirpated; historical records only. \\
\hline GH/NH/SH & Historically known; may be relocated in the future. \\
\hline G?/N?/S? & Not yet ranked, or rank tentatively assigned. \\
\hline
\end{tabular}

E. United States Endangered Species Act (after National Research Council 1995)

\begin{tabular}{|l|l|}
\hline Endangered & Any species that is in danger of extinction throughout all or a significant portion of its range. \\
\hline Threatened & $\begin{array}{l}\text { Any species that is likely to become an endangered species within the foreseeable future } \\
\text { throughout all or a significant portion of its range. }\end{array}$ \\
\hline
\end{tabular}




\section{List of Titles in This Series}

(as of April 2008)

No. 1 Status of the Piping Plover (Charadrius melodus) in Alberta, by David R. C. Prescott. 19 pp. (1997)

No. 2 Status of the Wolverine (Gulo gulo) in Alberta, by Stephen Petersen. 17 pp. (1997)

No. 3 Status of the Northern Long-eared Bat (Myotis septentrionalis) in Alberta, by M. Carolina Caceres and M. J. Pybus. 19 pp. (1997)

No. 4 Status of the Ord's Kangaroo Rat (Dipodomys ordii) in Alberta, by David L. Gummer. 16 pp. (1997)

No. 5 Status of the Eastern Short-horned Lizard (Phrynosoma douglassii brevirostre) in Alberta, by Janice D. James, Anthony P. Russell and G. Lawrence Powell. 20 pp. (1997)

No. 5 Update 2004. Status of the Short-horned Lizard (Phrynosoma hernandesi) in Alberta. Alberta Sustainable Resource Development. 27 pp. (2004)

No. 6 Status of the Prairie Rattlesnake (Crotalus viridis viridis) in Alberta, by Sheri M. Watson and Anthony P. Russell. 26 pp. (1997)

No. 7 Status of the Swift Fox (Vulpes velox) in Alberta, by Susan E. Cotterill. 17 pp. (1997)

No. 8 Status of the Peregrine Falcon (Falco peregrinus anatum) in Alberta, by Petra Rowell and David P. Stepnisky. 23 pp. (1997)

No. 9 Status of the Northern Leopard Frog (Rana pipiens) in Alberta, by Greg Wagner. 46 pp. (1997)

No. 9 Update 2003. Status of the Northern Leopard Frog (Rana pipiens) in Alberta. Alberta Sustainable Resource Development. 61 pp. (2003)

No. 10 Status of the Sprague's Pipit (Anthus spragueii) in Alberta, by David R. C. Prescott. 14 pp. (1997)

No. 11 Status of the Burrowing Owl (Speotyto cunicularia hypugaea) in Alberta, by Troy I. Wellicome. $21 \mathrm{pp}$. (1997)

No. 11 Update 2005. Status of the Burrowing Owl (Athene cunicularia) in Alberta. Alberta Sustainable Resource Development and Alberta Conservation Association. 28 pp. (2005)

No. 12 Status of the Canadian Toad (Bufo hemiophrys) in Alberta, by Ian M. Hamilton, Joann L. Skilnick, Howard Troughton, Anthony P. Russell, and G. Lawrence Powell. 30 pp. (1998)

No. 13 Status of the Sage Grouse (Centrocercus urophasianus urophasianus) in Alberta, by Cameron L. Aldridge. 23 pp. (1998)

No. 14 Status of the Great Plains Toad (Bufo cognatus) in Alberta, by Janice D. James. 26 pp. (1998)

No. 15 Status of the Plains Hognose Snake (Heterodon nasicus nasicus) in Alberta, by Jonathan Wright and Andrew Didiuk. 26 pp. (1998)

No. 16 Status of the Long-billed Curlew (Numenius americanus) in Alberta, by Dorothy P. Hill. 20 pp. (1998)

No. 17 Status of the Columbia Spotted Frog (Rana luteiventris) in Alberta, by Janice D. James. 21 pp. (1998) 
No. 18 Status of the Ferruginous Hawk (Buteo regalis) in Alberta, by Josef K. Schmutz. 18 pp. (1999)

No. 18 Update 2006. Status of the Ferruginous Hawk (Buteo regalis) in Alberta. Alberta Sustainable Resource Development and Alberta Conservation Association. 22 pp. (2006)

No. 19 Status of the Red-tailed Chipmunk (Tamias ruficaudus) in Alberta, by Ron Bennett. 15 pp. (1999)

No. 20 Status of the Northern Pygmy Owl (Glaucidium gnoma californicum) in Alberta, by Kevin C. Hannah. 20 pp. (1999)

No. 21 Status of the Western Blue Flag (Iris missouriensis) in Alberta, by Joyce Gould. 22 pp. (1999)

No. 21 Update 2005. Status of the Western Blue Flag (Iris missouriensis) in Alberta. Alberta Sustainable Resource Development and Alberta Conservation Association. 29 pp. (2005)

No. 22 Status of the Long-toed Salamander (Ambystoma macrodactylum) in Alberta, by Karen L. Graham and G. Lawrence Powell. 19 pp. (1999)

No. 23 Status of the Black-throated Green Warbler (Dendroica virens) in Alberta, by Michael R. Norton. 24 pp. (1999)

No. 24 Status of the Loggerhead Shrike (Lanius ludovicianus) in Alberta, by David R. C. Prescott and Ronald R. Bjorge. 28 pp. (1999)

No. 25 Status of the Plains Spadefoot (Spea bombifrons) in Alberta, by Richard D. Lauzon. 17 pp. (1999)

No. 26 Status of the Trumpeter Swan (Cygnus buccinator) in Alberta, by M. Lynne James. 21 pp. (2000)

No. 27 Status of the Pygmy Whitefish (Prosopium coulteri) in Alberta, by William C. Mackay. 16 pp. (2000)

No. 28 Status of the Short-eared Owl (Asio flammeus) in Alberta, by Kort M. Clayton. 15 pp. (2000)

No. 29 Status of the Willow Flycatcher (Empidonax traillii) in Alberta, by Bryan Kulba and W. Bruce McGillivray. 15 pp. (2001)

No. 30 Status of the Woodland Caribou (Rangifer tarandus caribou) in Alberta, by Elston Dzus. 47 pp. (2001)

No. 31 Status of the Western Spiderwort (Tradescantia occidentalis) in Alberta, by Bonnie Smith. 12 pp. (2001)

No. 32 Status of the Bay-breasted Warbler (Dendroica castanea) in Alberta, by Michael Norton. 21 pp. (2001)

No. 33 Status of the Cape May Warbler (Dendroica tigrina) in Alberta, by Michael Norton. 20 pp. (2001)

No. 34 Status of the Whooping Crane (Grus americana) in Alberta, by Jennifer L. White. 21 pp. (2001)

No. 35 Status of Soapweed (Yucca glauca) in Alberta, by Donna Hurlburt. 18 pp. (2001)

No. 36 Status of the Harlequin Duck (Histrionicus histrionicus) in Alberta, by Beth MacCallum. 38 pp. (2001)

No. 37 Status of the Grizzly Bear (Ursus arctos) in Alberta, by John L. Kansas. 43 pp. (2002)

No. 38 Status of the Wood Bison (Bison bison athabascae) in Alberta, by Jonathan A. Mitchell and C. Cormack Gates. 32 pp. (2002) 
No. 39 Status of the Bull Trout (Salvelinus confluentus) in Alberta, by John R. Post and Fiona D. Johnston. 40 pp. (2002)

No. 40 Status of the Banff Springs Snail (Physella johnsoni) in Alberta, by Dwayne A.W. Lepitzki. 29 pp. (2002)

No. 41 Status of the Shortjaw Cisco (Coregonus zenithicus) in Alberta, by Mark Steinhilber. 23 pp. (2002)

No. 42 Status of the Prairie Falcon (Falco mexicanus) in Alberta, by Dale Paton. 28 pp. (2002)

No. 43 Status of the American Badger (Taxidea taxus) in Alberta, by Dave Scobie. 17 pp. (2002)

No. 44 Status of the Yucca Moth (Tegeticula yuccasella) in Alberta. Alberta Sustainable Resource Development. 21 pp. (2002)

No. 45 Status of the White-winged Scoter (Melanitta fusca deglandi) in Alberta. Alberta Sustainable Resource Development. 15 pp. (2002)

No. 46 Status of the Lake Sturgeon (Acipenser fulvescens) in Alberta. Alberta Sustainable Resource Development. 30 pp. (2002)

No. 47 Status of the Western Silvery Minnow (Hybognathus argyritis) in Alberta. Alberta Sustainable Resource Development. 24 pp. (2003)

No. 48 Status of the Small-flowered Sand Verbena (Tripterocalyx micranthus) in Alberta. Alberta Sustainable Resource Development. 24 pp. (2003)

No. 49 Status of the Brown Creeper (Certhia americana) in Alberta. Alberta Sustainable Resource Development. 30 pp. (2003)

No. 50 Status of the Mountain Plover (Charadrius montanus) in Alberta. Alberta Sustainable Resource Development. 25 pp. (2003)

No. 51 Status of the St. Mary Shorthead Sculpin (provisionally Cottus bairdi punctulatus) in Alberta. Alberta Sustainable Resource Development. 24 pp. (2003)

No. 52 Status of the Stonecat (Noturus flavus) in Alberta. Alberta Sustainable Resource Development. 22 pp. (2003)

No. 53 Status of the Sage Thrasher (Oreoscoptes montanus) in Alberta. Alberta Sustainable Resource Development. 23 pp. (2004)

No. 54 Status of the Tiny Cryptanthe (Cryptantha minima) in Alberta. Alberta Sustainable Resource Development. 39 pp. (2004)

No. 55 Status of the Slender Mouse-ear-cress (Halimolobos virgata) in Alberta. Alberta Sustainable Resource Development. 27 pp. (2005)

No. 56 Status of the Barred Owl (Strix varia) in Alberta. Alberta Sustainable Resource Development. 15 pp. (2005)

No. 57 Status of the Arctic Grayling (Thymallus arcticus) in Alberta. Alberta Sustainable Resource Development. 41 pp. (2005)

No. 58 Status of the Weidemeyer's Admiral (Limenitis weidemeyerii) in Alberta. Alberta Sustainable Resource Development and Alberta Conservation Association. 13 pp. (2005) 
No. 59 Status of the Porsild's Bryum (Bryum porsildii) in Alberta. Alberta Sustainable Resource Development and Alberta Conservation Association. 30 pp. (2006)

No. 60 Status of the Western Grebe (Aechmophorus occidentalis) in Alberta. Alberta Sustainable Resource Development and Alberta Conservation Association. 29 pp. (2006)

No. 61 Status of the Westslope Cutthroat Trout (Oncorhynchus clarkii lewisii) in Alberta. Alberta Sustainable Resource Development and Alberta Conservation Association. 34 pp. (2006)

No. 62 Status of the Limber Pine (Pinus flexilis) in Alberta. Alberta Sustainable Resource Development and Alberta Conservation Association. 17 pp. (2007)

No. 63 Status of the Whitebark Pine (Pinus albicaulis) in Alberta. Alberta Sustainable Resource Development and Alberta Conservation Association. 22 pp. (2007)

No. 64 Status of the Western Small-footed Bat (Myotis ciliolabrum) in Alberta. Alberta Sustainable Resource Development and Alberta Conservation Association. 24 pp. (2008)

No. 65 Status of the Verna's Flower Moth (Schinia verna) in Alberta. Alberta Sustainable Resource Development and Alberta Conservation Association. 17 pp. (2008) 


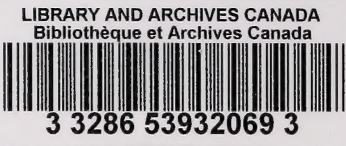

